\title{
Utilization of Educational Games in the Implementation of Strengthening Character Education
}

Sulastri ${ }^{1 凶}$, YL Sukestyarno ${ }^{2}$, Nurhasanah ${ }^{3}$

${ }^{1}$ SDN Wanareja 01 Cilacap, Jawa Tengah, Indonesia

${ }^{2}$ Program Studi Pendidikan Dasar, Program Pascasarjana, Universitas Terbuka, Indonesia

${ }^{3}$ Program Studi Pendidikan Dasar, Program Pascasarjana, Universitas Terbuka, Indonesia

凶 email: lastri354@gmail.com

\section{Received:}

01 December

2021

\section{Revised:}

02 December

2021

\section{Accepted:}

02 January 2022

Published:

02 January 2022

\begin{abstract}
Educational games are simulation-based media designed to simulate existing problems so that the essence of knowledge is obtained that can be used to solve problems. This study aims to produce a Character Education Strengthening device product in the form of a syllabus, teacher guide book, student guide book assisted by appropriate educational games, which have a level of product validity and practicality. Obtaining the product begins with conducting a preliminary study through literature studies, learning observations, testing to validators, limited-scale trials, revisions, products, main-scale trials, and final products. This study uses the type of research and development with the flow of Borg \& Gall with stages from preliminary studies to field trials. The data collection instruments used were validation sheets, student response questionnaires, teacher responses, and observation sheets for the teacher's ability to use the product. The results showed that the product development in the form of a syllabus supplement obtained a score of $82.75 \%$. At the same time, the product development of the Character Education Strengthening guidebook for teachers got a validation value from the validator of $84.66 \%$. It obtained a validation value from the validator of $81.23 \%$. Experimental test data for student responses scored $83.80 \%$, and teacher responses reached $86.90 \%$. It means that the development product falls into the very valid, very practical, and feasible.
\end{abstract}

Keywords: Learning Devices, Strengthening Character Education, Educational Games.

\section{INTRODUCTION}

The initial concept of developing a Character Education Strengthening device with the help of educational games is the characteristic of elementary school students who like to play. Playing is an activity carried out with or without using tools that generate understanding or provide information, give pleasure or develop imagination in children (Anggani Sudono, 2000). Based on the principle of play while learning, this game takes students to a world where character cultivation that was once boring becomes fun. This game arouses students' interest because they feel challenged to complete it. 
Elementary school students are seven to thirteen years old in the concrete operational stage. Thus, the teacher should help concretize this problem by using learning media. The level of education in elementary school is fundamental in improving human resources (Syaodih, 2006). At this level, essential abilities and skills are developed in students. A longitudinal study conducted by Bloom (Syaodih, 2006) illustrates that the general academic achievement of children is determined by the academic achievement of children at elementary school age. This finding demonstrates that children's first years of learning in elementary school have a significant effect on attitudes and patterns of children's subsequent achievement.

This study applies media to help students implement Strengthening Character Education with various educational games. Educational games are very interesting for students. One of the main advantages is that pleasant visualization can activate all students' senses so that incoming stimulation can be easily digested. Children gain understanding and are meaningful for their lives. Educational games aim to form independence because they learn media by making patterns. Based on this pattern, students as players must know to solve their problems.

The development of globalization, which is moving very fast, has contributed to education, both directly and indirectly. The result of globalization now has an impact on the world of education. The global value system influences the culture of developing countries by entering the culture of developed countries. The world of education is faced with demands to prepare students to face changes, especially aspects of values and morals. The moral and character decades have shown by students are closely related to the world of education-for example, violence, morality issues, rape, and murder. The consequences are pretty severe and can no longer be considered a simple problem. Things that often appear in everyday life, for example, are cheating, plagiarizing, and looking for reasons to run away from responsibilities (Koesoema, 2009).

The world of education makes an extraordinary contribution to overcoming these problems. In the context of formal education, one of the reasons is that it focuses only on the cognitive aspects of students so that other elements are not given much attention. As the successor to the nation's generation, elementary school children should be young people born with various thoughts and personalities with good morals, which are the main targets of technological crimes. The impact of demoralization is a decline in the civilization of society.

Character education comes from two words, namely education, and character. According to Koesoema (2007), education internalizes culture into individuals and society to be civilized. In law number 20 of 2003 concerning the National Education System in article 1 paragraph (1), it is stated that education is a conscious and planned effort to form a learning atmosphere and learning process to develop students actively develop their potential to have religious-spiritual strength, selfcontrol, personality, intelligence, noble character, and skills needed by himself, society, nation, and state. 
Character formation cannot be separated from the role of the world of education. In educating students, an educator must create an effective learning process. According to Suyono (2015), the learning process includes cognitive, psychomotor, and affective elements. Learning is a term that has a very close relationship and cannot be separated from one another with the educational process. Learning is an activity carried out to create an atmosphere or provide learning services. Ideally, given the importance of learning, applying the proper learning tools is necessary. Learning tools have a strategic role in boosting the success of the teaching and learning process because the application of learning tools sees the condition of students' needs.

Elementary school students are subjects that need attention from the start. Elementary school is short, but it is critical for the next life. It is necessary to encourage and develop students' potentials to become provisions for the future. Elementary school children are a perfect initial stage in developing character education in children. By the stages of child development, the characteristics of the way children learn, learning concepts, and meaningful learning, learning activities for elementary school children should be carried out by taking into account the parts of elementary school children.

The Public Elementary School of Wanareja 01 Cilacap has strengthened character education based on a preliminary study. However, its implementation has not involved all elements of the school. The strengthening of existing character education is only limited to a theoretical introduction or character education discourse. It was also emphasized that the current curriculum was still having difficulties, even though there was already assistance from teacher and student books. It shows that character education has only touched the level of knowledge of norms or values and not yet at the level of internalization and real action in everyday life.

Based on this description, it is necessary to formulate the design of Character Education Strengthening devices that can help provide solutions to these problems. The Character Education Strengthening Tool will be developed more operationally in elementary schools. Its obtained is expected to help determine steps or policies in the form of improvement steps or improving the character quality of students at The Public Elementary School of Wanareja 01 Cilacap.

\section{METHOD}

This research uses a research and development model based on the research objectives. One is the $\mathrm{R}$ and $\mathrm{D}$ Borg \& Gall Model. The selection of this type of development is considered appropriate for several reasons, namely (1) it has systematic stages so that it can be carried out correctly and produces a decent product, (2) a preliminary study is carried out so that the actual problems that occur can be known, (3) the product developed through a trial process so that it can be seen the level of product feasibility, both the level of validity, and practicality, (4) revision activities make the resulting product more perfect. 
In this study, there were several stages of development, according to Borg \& Gall (1983), which were arranged with modifications and adapted to research needs without reducing the substance of the product development procedure. Adjustments were made to support the development process to better suit the research focus. The results of this development are focused on overcoming problems in the implementation of Strengthening Character Education. The researchers modified the development steps of Borg \& Gall (1983) because, in this study, the researchers did not have sufficient time and money to carry out product dissemination activities.

In this regard, using the stages in these development steps comes to the main field trial. The research and development steps that will be carried out in this research are (1) research and information gathering, (2) planning, (3) product development, (4) initial field trials, (5) revision of test results, (6) the main field trial, and (7) the final product.

A more detailed explanation of the development procedure that will be passed in this research can be seen as follows-first, research and information gathering. The first step in this research is to conduct a preliminary study. The activities carried out include (a) field studies by conducting observations and interviews (Apriyanto, 2019; Apriyanto et al., 2020; Apriyanto \& Anum, 2018), (b) literature study, (c) problem analysis, and (d) needs analysis. The second is planning. The activities carried out in planning include the stages (a) formulating goals, (b) establishing a model for implementing Character Education Strengthening, (c) determining the type of educational game. Third, product development. Researchers carry out product development by drafting a prototype device developed at this stage. Then proceed with making learning tools in a syllabus, teacher guidebooks, student manuals, and validation to learning expert validators.

The initial product draft development stage was carried out by compiling a product development in a prototype syllabus supplement, a Character Education Strengthening guide book for teachers, and a student pocketbook. The activities contained in the product development include class-based Character Education Strengthening, school culture-based Character Education Strengthening, and community-based Character Education Strengthening. The components in the syllabus supplement include academic unit, type of activity, and columns (description of activities, objectives, character developed, brief description of activities, allocation of time used, assessment, and learning resources). While the Character Education Strengthening guidebooks and student pocketbooks include: activity names, Character Education Strengthening scores, educational games that can be used, student task descriptions, assessments, and sources. The educational games used include traditional games, standby/scout games, various puzzles, digital games. 

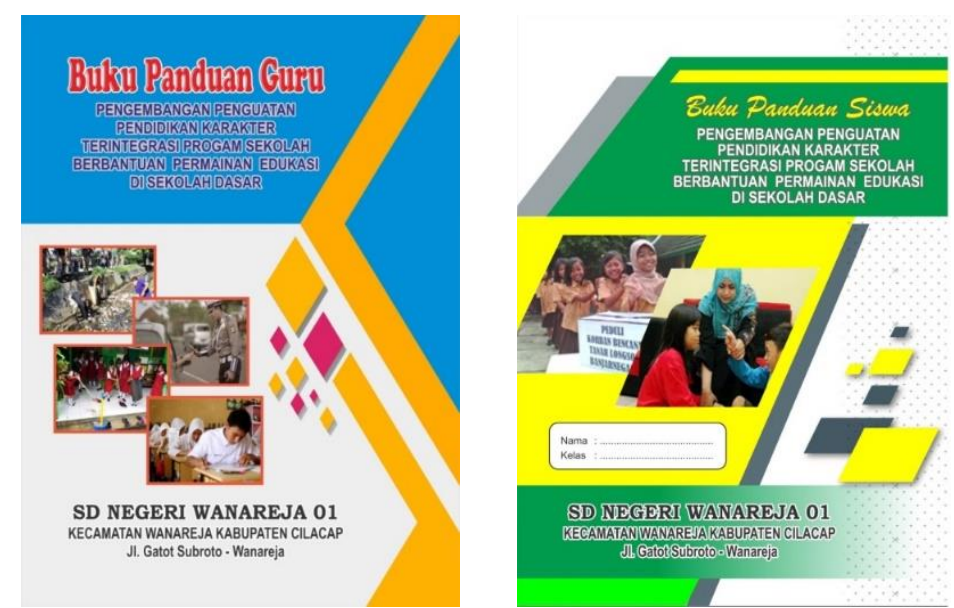

Picture of Character Education Strengthening Guidebook for Teachers and Students

\section{Product Trial Description}

The initial draft of the product developed in a syllabus supplement, teacher manual, and student pocketbook was further validated by two experts, namely a material expert and a design expert. Material experts tested aspects: material/content, presentation, graphics, and language. Meanwhile, the design experts tested the following elements: cover design, content design, and clarity. In addition to validating these aspects, expert validators are also asked to provide suggestions and input on product development as revision material. The recapitulation of the expert validators is presented in table 1.

Table 1. Recapitulation of Expert Validation Results

\begin{tabular}{|c|c|c|c|c|c|c|c|}
\hline \multirow{3}{*}{ No } & \multirow{3}{*}{ Validator } & \multicolumn{6}{|c|}{ Character Education Strengthening Tool } \\
\hline & & \multicolumn{2}{|c|}{ Syllabus } & \multicolumn{2}{|c|}{ Teacher's Guidebook } & \multicolumn{2}{|c|}{ Students' Guidebook } \\
\hline & & Material & Design & Material & Design & Material & Design \\
\hline 1 & Val 1 & 78,13 & 83,66 & 78,13 & 83,49 & 78,13 & 83,66 \\
\hline 2 & Val 2 & 90,63 & 89,84 & 90,63 & 86,51 & 81,88 & 86,51 \\
\hline \multirow[t]{5}{*}{3} & Val 3 & 87,50 & 81,82 & 87,50 & 81,82 & 80,63 & 81,82 \\
\hline & Total & \multicolumn{2}{|c|}{165,50} & \multicolumn{2}{|c|}{169,32} & \multicolumn{2}{|c|}{162,45} \\
\hline & & \multicolumn{2}{|c|}{82,75} & \multicolumn{2}{|c|}{84,66} & \multicolumn{2}{|c|}{81,23} \\
\hline & Average & \multicolumn{6}{|c|}{82,88} \\
\hline & Criteria & \multicolumn{6}{|c|}{ Extremely Valid } \\
\hline
\end{tabular}

Based on the recapitulation results of the expert validation results presented in the table above, it can be seen that the level of syllabus validity in the first validation obtained an average score of $82.75 \%$. The Strengthening Character Education Guide for teachers received a score of $84.66 \%$, and the Strengthening Education Characters Guidebook for students scored $81.23 \%$. Thus, in the first validation of product development in the form of a syllabus supplement and the Strengthening Education Characters Guidebook assisted by educational games, $82.88 \%$ of the criteria were very valid, meaning that the product can be used without requiring revision. In the first validation stage, the supplementary syllabus and the 
Strengthening Education Characters Guidebook have reached very valid criteria to be used for limited trials.

The next stage, namely the limited trial, was held on September 5, 2018. The little trial involved six students of The Public Elementary School of Wanareja 01. Each student represented a high, medium, and low academic ability. A limited test was conducted to obtain student responses to the Strengthening Education Characters Guidebook and student pocketbooks. In addition to student response data from questionnaires, the little trial also received data from teacher response questionnaires related to the practicality of the syllabus supplement and Education Characters Guidebook guide book.

\section{Product Trial Description}

Fourth is initial field product trials. The products that have been developed and revised based on the validation results by expert validators were tested on a small scale to 6 fourth-grade students at The Public Elementary School of Wanareja 01 Cilacap.

The subsequent trial is the primary field trial. This trial was conducted in the fourth grade of The Public Elementary School of Wanareja 01 Cilacap, with 35 students. After the revision, the final product was obtained in the form of a product developed by the researcher and used to create Strengthening Character Education with the help of educational games in elementary school.

Product trials are carried out to know the level of practicality of the products that have been developed.

\section{Table 2. Recapitulation of Responses from Practical Aspects}

\begin{tabular}{|l|l|c|c|}
\hline No & Trial Subject & Score Percentage & Criteria \\
\hline 1 & Students to guidebook & $83,80 \%$ & Very Practical \\
\hline 2 & Teacher to syllabus and guidebook & $86,90 \%$ & Very Practical \\
\hline 3 & Teacher's Ability & $80,05 \%$ & Very Practical \\
\hline \multicolumn{2}{|c|}{ Total score } & 250,75 & Very Practical \\
\hline
\end{tabular}

\section{FINDINGS AND DISCUSSION}

The research and development carried out resulted in a character education strengthening device product. The resulting devices are the syllabus, teacher's guidebook, and student's guidebook. Based on the instrument of expert validation results obtained about the product developed by the researcher in the study, the percentage of product validity was $82.88 \%$. From the rate received, it can be seen quantitatively that the level of reality is very valid and feasible.

The product can be developed to strengthen character education activities at The Public Elementary School of Wanareja 01. The average score of the teacher's ability to manage Character Education Strengthening implementation in all meetings is $80.05 \%$. From this percentage, it can be seen qualitatively that the practicality of the Character Education Strengthening implementation tools developed is efficient. 
In a limited trial, suggestions and input were obtained from the six students as test subjects, namely the pocketbook and Character Education Strengthening guidebook, which was developed very interestingly. A student gave reasons why the Character Education Strengthening guidebook had good material, exciting pictures, learning accompanied by play, not dull. Suyono (2015) states that elementary schoolaged children like exciting things. I obtained $82.50 \%$ of product development practicality for qualitative data with very valid criteria.

The limited trial involved six students of The Public Elementary School of Wanareja 01. Each student represented a high, medium, and low academic ability. A little test was conducted to obtain student responses to the reading culture guidebook and students' pocketbooks. The questionnaire results on student responses to the Character Education Strengthening guidebook and students' pocketbook got $87.09 \%$ with efficient criteria. Meanwhile, the teacher's response questionnaire to the syllabus supplement and reading culture guidebook received a score of $82.50 \%$ with efficient standards. Thus, the product development was considered very practical and feasible to use at the limited trial stage, with an average value of $84.80 \%$.

Field trials were carried out by applying three Character Education Strengthening implementation models: classroom-based Character Education Strengthening, school culture class-based Character Education Strengthening, and community-based Character Education Strengthening. The observation of the teacher's ability in the Character Education Strengthening implementation model obtained a score of $80.05 \%$ with very practical criteria. At the same time, the results of the student response questionnaire to the Character Education Strengthening guidebook and students' pocketbook obtained a score of $83.80 \%$ with very practical criteria. Thus, at the field trial stage, development products in syllabus supplements, Character Education Strengthening guide books, and students' pocketbooks were considered very practical, engaging, and applicable, with an average value of $83.58 \%$.

Based on the data in the main field trial, it is known that the student response score to the implementation of Character Education Strengthening during the trial process shows a percentage score of $83.80 \%$. Obtaining these scores indicates that students positively responded to Character Education Strengthening implementation using the developed tools. The tools can be implemented well in schools, and most students feel happy doing Character Education Strengthening implementation activities. Students seemed to be doing more activities in the trial, not just listening to the teacher's description. The student's training is by the benefits of the learning media proposed (Sukiman, 2012).

In infield trials of community-based Character Education Strengthening implementation activities, students were interested in playing puzzles in groups. The implementation of Character Education Strengthening looks more interesting when the class activities are inspired. Medical personnel from the Community Health Centers I Wanareja brought a game of health snakes and ladders; the students enjoyed the training. Likewise, the Wanareja Sector Police members asked students to play a puzzle about traffic signs. This follows elementary school children's social 
characteristics, often referred to as the age group. Children at elementary school age have a great interest in peer activities and a desire to be accepted as group members (Suyono, 2015).

\section{CONCLUSION}

This product development is carried out to produce a proper Character Education Strengthening device. The feasibility of this device is based on two criteria, namely validity and practicality. The product developed by this researcher is fundamental to determining the level of product feasibility before being used in field trials. Based on the validation results obtained information that the validity of the product with a very valid category can be used. From these results, the implementation tools developed are theoretically valid and can be used in Character Education Strengthening implementation activities. Nieveen's (1999) statement that the validity of a product is based on its conformity with the theory.

The practicality test of the product developed aims to determine the ease of use of the product. Based on the observations of teachers' abilities in implementing character education strengthening, the percentage obtained good results, with very practical criteria to be used. The developed device makes students active and enthusiastic in participating in Character Education Strengthening implementation activities. Nieven's (1999) opinion is that the practicality of a product is based on the product's ability to achieve learning/activity goals.

\section{ACKNOWLEDGMENTS}

Suggestions for utilization in this study are syllabus supplement products and guidebooks for Strengthening Character Education assisted by educational games that can be used or applied to other schools to improve student character. Teachers must motivate students that character is a crucial and valuable thing. Teachers must also be creative in choosing which activities are suitable for the low class and which exercises are ideal for the high class.

Suggestions for dissemination for product development in this research, the dissemination activity begins with an explanation of how to develop a syllabus supplement and a guide book for Strengthening Character Education with the help of educational games. Then the dissemination continued with questions and answers about product development. Participants' suggestions and input about the syllabus supplement product and the guidebook for Strengthening Character Education assisted by educational games were collected as input for researchers. This development product can be used as a guide for other teachers to develop forms of Character Education Strengthening implementation activities tailored to the characteristics of students in each school. This development product is used as a guideline. It is disseminated and further developed through the KKG (Teacher Working Group) in the cluster, sub-district, and district levels. 


\section{REFERENCES}

Apriyanto, S. (2019). Gender Strategies in Learning English (Junaidi (ed.); 1st ed., Vol. 73). Sulur Pustaka. www.sulur.co.id

Apriyanto, S., \& Anum, A. (2018). Gender Dynamics on Speaking Interaction in the $\begin{array}{lllll}\text { College Classroom. Jurnal Smart, } & 4(2), & 73 .\end{array}$ https://doi.org/10.26638/js.692.203x

Apriyanto, S., Dalman, \& Santoso, D. (2020). The urgency of forensic linguistics in a police interrogation process. International Journal of Psychosocial Rehabilitation, 24(6), 4766-4772. https://doi.org/10.37200/IJPR/V24I6/PR260467

Borg, W.R. \& Gall, M.D. (1983). Educational Research: An Introduction Fifth edition. New York: Longman

Ditjen Pendidikan Dasar dan Menengah. (2003). Undang-Undang Nomor 20 Tahun 2003 Tentang Sistem Pendidikan Nasional. Jakarta: Depdikbud

Ismail, Andang. (2006). Education Games: Menjadi Cerdas Dan Ceria Dengan Permainan Educatif, Yogyakarta: Pilar Media.

Koesoema , Doni. (2019). Pendidikan Karakter: Utuh dan Menyeluruh, Yogyakarta: Kanisius.

Nieveen dkk. (1999). Principle and Method of Development Research. London: Kluwer Academic Publisher

Sukiman, (2012). Pengembangan Media Pembelajaran. Yogyakarta: Pedagogia

Sudono, Anggani. (2000). Sumber Belajardan Alat Permainan Untuk Pendidikan. Jakarta: PT Raja Grafindo Persada.

Suyono. (2015). Belajar Dan Pembelajara .Bandung: Remaja Rosda Karya 